Research Article

\title{
Understanding the bottlenecks in methodological adoption of constructivism in secondary schools in Kenya
}

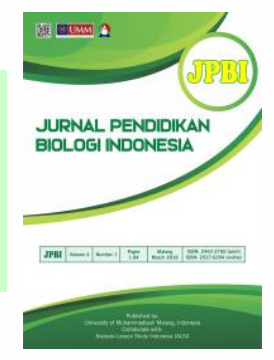

\author{
Gideon Mwanda a,1, , Ronnie Midigo b,2,* \\ a Asumbi Teacher's Training College and Department of Education Communication and Technology, University of Nairobi, P. O. Box $30197-00100$ \\ Nairobi, Kenya \\ ${ }^{b}$ Institute of Anthropology, Gender and African Studies, University of Nairobi, P. O. Box 30197 - 00100, Nairobi, Kenya \\ ${ }^{1}$ gmmwanda@gmail.com; ${ }^{2}$ ronniemidigo@gmail.com* \\ * corresponding author
}

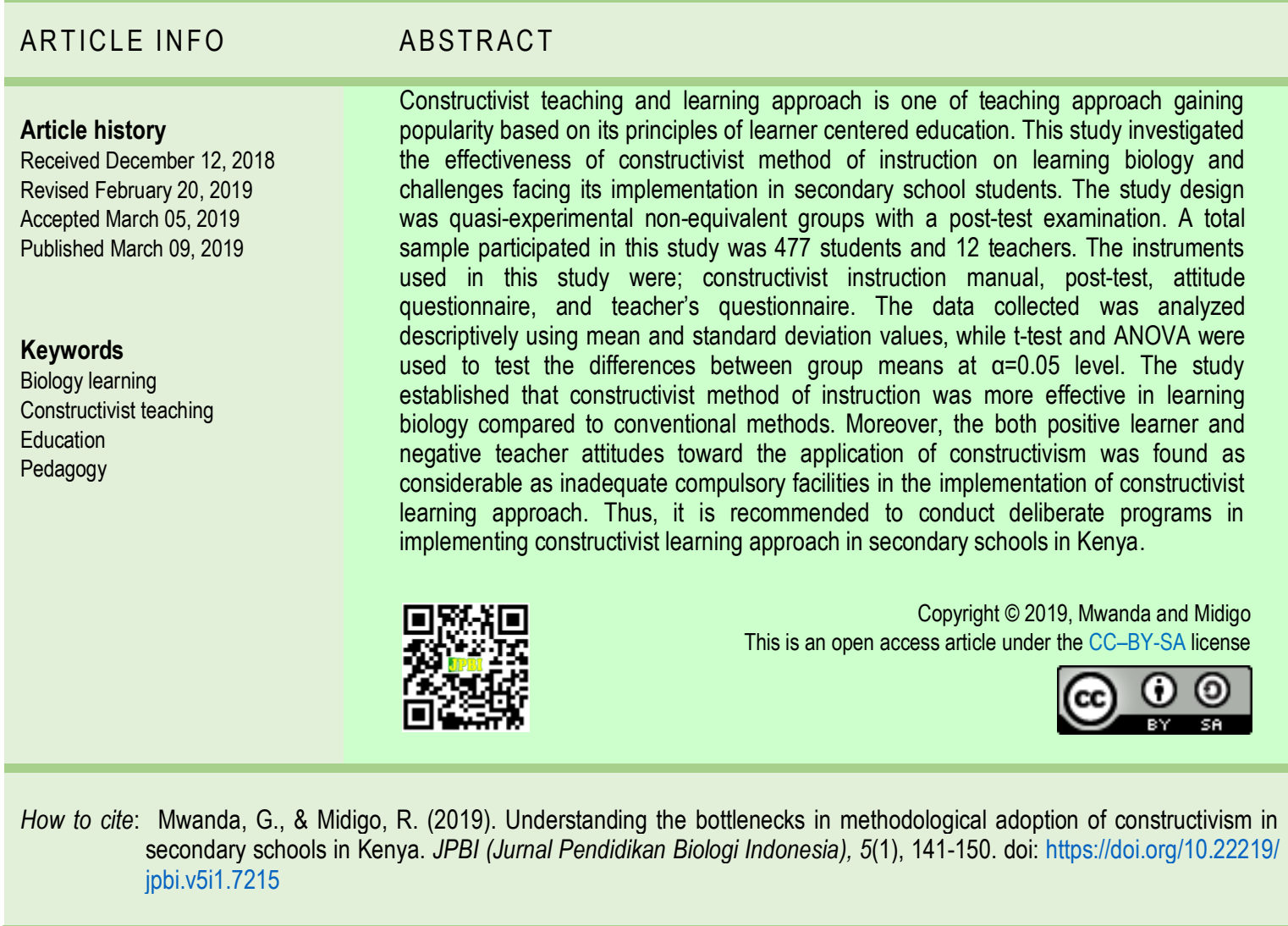

\section{INTRODUCTION}

Teaching and learning biology in many secondary schools in Kenya has generally taken a pattern where teachers mostly use instructional methods characterized by lectures and few demonstrations (Gideon M. Mwanda, Paul Odundo, Ronnie Midigo, \& Owino S. Mwanda, 2016; Mukhwana, 2016; Ngesu, Gunga, Wachira, \& Kaluku, 2014; Nyongesa, 2015; Ouko, Anditi, \& Githua, 2017; Vidija, 2015). These instructional methods expose students to minimal practical activities, group discussions, and are hardly taken on educational trips 
(Allybokus, 2015; Jepketer, 2017; Jidamva, 2012). Consequently, learner achievement in biology has been poor.

On the other hand, an application of learner-centered instructional approaches has a greater potential in enhancing learner achievements (Andersen \& Andersen, 2017; Connell, Donovan, \& Chambers, 2016; Hsu, Wang, \& Levesque-Bristol, 2019; Izzo, 2012; Kharb, Samanta, Jindal, \& Singh, 2013; Laal, Naseri, Laal, \& Khattami-Kermanshahi, 2013; McKnight et al., 2016; Montrieux, Vanderlinde, Schellens, \& De Marez, 2015; Öhrstedt \& Lindfors, 2018; Zenda, 2017). This study considered application of constructivism as espoused by Piaget and Inhelder (1964) in teaching and learning Biology for better learner achievements. This approach is herein referred to as individual constructivist theory.

Individual constructivist theory of Piaget and Inhelder (1964) provides a two-pronged approach to knowledge construction. First, Piaget's cognitive structures (schema) which responsible for adaptation processes of assimilation, accommodation and equilibrium are like use of prior-learning experiences in aiding new knowledge constructions. Second, learning occurs when an individual pass through four stages of cognitive developments: sensory-motor, pre-operational, concrete and formal operational stages. Concrete and formal operational stages are implied in constructivist learning. At the concrete stage, learning is by manipulating objects, ideas, and events which later are transformed to formal reasoning. In constructivist learning, repeated manipulation of objects and ideas enables learners to construct meaningful concepts that can be transferred to logical abstract reasoning in a formalized manner.

The social constructivist learning theory proposed by Vygotsky in 1978, considered learning as a socially mediated exercise where a person constructs his/her knowledge based on his/her interactions with social and cultural environment (Hakkarainen, Paavola, Kangas, \& Seitamaa-Hakkarainen, 2015; Shabani, 2016; Shabani, Khatib, \& Ebadi, 2010; Thomas, Menon, Boruff, Rodriguez, \& Ahmed, 2014; Verenikina, 2010; Vygotsky, 1978; Wang, Bruce, \& Hughes, 2011). Knowledge formed by a learner is influenced by environment (context) and prior knowledge held by the learner (Jang, Kim, \& Reeve, 2016; Kimmerle, Moskaliuk, Oeberst, \& Cress, 2015; van Riesen, Gijlers, Anjewierden, \& de Jong, 2018). Therefore, in social constructivist learning, teachers should provide learners with opportunity to negotiate meaning and to collaborate with peers and adults including teachers in knowledge construction (Adams, 2006; Jafari Amineh \& Davatgari Asl, 2015; Jang et al., 2016; Lai, 2011; Mensah, 2015; Piaget \& Inhelder, 1956).

Based on the advantages mentioned above, however, the evaluations of constructivist approach adopted in Kenya are still limited. Thus, the 5E's (Engage, Explore, Explain, Elaborate, Evaluate) constructivist was adopted in this study, a social constructivist approach in learning activities, was applied to provide learners with opportunities in constructing knowledge at individual and social levels during group discussions. In sense of assessing the effectiveness of constructivist instructional approach on learning biology as well as comprehending the challenges faced as its implementation in secondary school.

\section{METHOD}

This study was quasi-experimental non-equivalent group with post-test design. Both teachers and biology learners were the study population and examined in ecology topic. The participants in the study were divided into two groups i.e. experimental and control groups. The experimental group was exposed with constructivist instructional approach, while the control group was taught in conventional instructional method. A total of 477 students and 12 teachers were sampled to participate in this study. Research data were collected using posttest as well as a structured questionnaire. The all data collected were analyzed using both descriptive (mean and standard deviation) and differential statistics (t-test at $\alpha=0.05$ level).

\section{RESULTS AND DISCUSSION}

\section{Comparing constructivist and conventional instruction}

In attempting to investigate the effects of constructivist and conventional instructional approaches on learning biology, the post-test results gained in the both groups were analyzed and compared. This analysis was conducted in two ways: first, the total of post-test results for all participants in the both groups were analyzed and compared using descriptive statistics as well as t-test to observe whether there was a significant difference between the two groups. The analysis results are served in Table 1. Second, post-test results of the two groups were also analyzed and compared based on six cognitive levels. 
Table 1. Posttest results for the constructivist and conventional groups

\begin{tabular}{lccccc}
\hline Instructional group & Number of candidates & $\mathbf{M}$ & $\mathbf{S D}$ & $\boldsymbol{t}$-test & $\boldsymbol{p}$-value \\
\hline Constructivist & 231 & 45.84 & 15.05 & & \\
Conventional & 246 & 40.26 & 13.96 & 4.17 & 0.001 \\
\hline
\end{tabular}

The results in Table 1 indicate that the participants in experimental group $(M=45.84, S D=5.05)$ performed significantly better over their peers in the conventional group $(M=40.26, S D=13.96), t(475)=4.17, p<.001$ in which the alpha level of .05 .

The results obtained imply that participants who were exposed to constructivist method of instruction had a better understanding of the information covered during the period of instruction than those who were exposed to conventional methods. In the sense that constructivist instructional approach is more effective in promoting learning (Eilam \& Trop, 2012) of biology amongst students at secondary school compared to the conventional one. The assumed undergirding reason of this condition was the various activities conducted in constructivist group had engaged the students during the learning. Not only did the participants in constructivist group make working groups, but they also collaboratively worked on task items once the classes were engaged (Jafari Amineh \& Davatgari Asl, 2015).

Discussions, presentations, elaborations, and critique activities that formed key aspects of constructivist instruction enhanced understanding and memory of participants in the constructivist group (Andersen \& Andersen, 2017; Connell et al., 2016; Hsu et al., 2019; Izzo, 2012; Kharb et al., 2013; Laal et al., 2013; McKnight et al., 2016; Montrieux et al., 2015; Öhrstedt \& Lindfors, 2018; Zenda, 2017). The engagement phase provided learners with opportunity and much needed scaffolding which made them more focused and clearer on how to carry out investigations and what to discuss in the groups. During the discussions, participants constructed their own knowledge and tested it within the groups hence. This provided them a space for immediate feedback and motivation to seek for more information from various possible sources. During elaboration phase, the participants were presented with new tasks. Those tasks were related to what they had learned earlier so that the participants got opportunity to expand their horizons of thought as they reflected on the new tasks.

The idea of teachers building on learners' prior knowledge was similarly elaborated by Powell and Kalina (2009) who recommended that teachers should assist learners to make meaningful connections between prior knowledge and new information. The 5E constructivist model, in this study, provided teachers with opportunity to assist students in constructing connections between prior knowledge and new knowledge experiences which, in turn, can lead them to the better performance in posttest compared to pretest. Powell and Kalina (2009) also recognized the importance of cooperative element in constructivist instructional approach as a way of promoting competition among groups in a class. Thus, providing students with motivation and excitement will lead them to improve their performance. In a similar way, Lord (1999) explained the superiority of constructivist instructional approach over the traditional one on its chances in allowing group discussion and interaction. As the consequences, the positive interdependence formed among students with individual accountability resulted the better learning outcomes.

This study also compared the effects of the two instructional approach on learning biology in the six cognitive levels classified by Bloom (2000). Table 2 presents the posttest analysis results of the both constructivist and conventional groups. The results in Table 2 indicates that participants who experienced the constructivist instructional approach (experimental group) enacted the higher scores in four levels i.e. knowledge, comprehension, application, and evaluation levels compared to those who were exposed with conventional instructional approach (control group). The t-test analysis results show the significant differences in cognitive domain levels between the two groups. T-test results of the aspects observed were: Knowledge, $t(475)=4.19, p<0.001$; Comprehension, $t(475)=5.36, p<0.001$; Application, $t(475)=4.78, p<0.001$; and Evaluation, $t(475)=3.00, p<0.003$. Notwithstanding that four of the six aspects measured indicated that the experimental group levels were higher, but, contrarily, the two remain aspects, analysis $(M=60.33, S D=$ 23.37), $t(475)=0.09, p<0.93$ and synthesis $(M=63.41, S D=28.69), t(475)=3.02, p<0.003$ levels of control group were better compared to the experimental group (Analysis $(M=60.13, S D=23.69)$; Synthesis $(M=$ $55.45, S D=29.08)$ ). These results revealed that the analysis performance between control group and experimental group was insignificant; meanwhile, the synthesis ability was significantly different in favor of the control group.

The results presented in Table 2 show a decrease trend of students' achievement score from the lowest cognitive level (knowledge) to the highest one (evaluation). In the other words, the higher the cognitive level, 
the more difficult the cognitive level to be enacted by students. Even though this common phenomenon occurred, however, the students' ability in analyzing as well as synthesizing were defied the trend. The both cognitive levels were achieved better by participants compared to the other lower cognitive levels. It is assumed that the phenomena is accordance with Lake Wobegon effect (Thorndike, R. M., \& Thorndike-Christ, 2010). Lake Wobegon effect is an attempt to explain causes of inflation of a test result based on experience of participants before taking a test. In this study, either the biology teachers revised with participants' some items like items four and five in the posttest or the participants' themselves engaged on self-revision of question items on topic ecology before the posttest. This was assumed as the cause which resulted inflated scores for the two items (Analyzing and Synthesizing).

Table 2. Post-test Results for participants at different cognitive levels

\begin{tabular}{|c|c|c|c|c|c|}
\hline Cognitive Levels & Group & M & SD & $t$-value & $p$-value \\
\hline Knowledge & $\begin{array}{l}\operatorname{Exp}(n=231) \\
\text { Control }(n=246)\end{array}$ & $\begin{array}{l}56.41 \\
44.67\end{array}$ & $\begin{array}{l}31.75 \\
29.41\end{array}$ & 4.189 & $<0.001$ \\
\hline Application & $\begin{array}{l}\operatorname{Exp}(n=231) \\
\text { Control }(n=246)\end{array}$ & $\begin{array}{l}37.45 \\
25.73\end{array}$ & $\begin{array}{l}28.05 \\
25.49\end{array}$ & 4.778 & $<0.001$ \\
\hline Analysis & $\begin{array}{l}\text { Exp(n=231) } \\
\text { Control }(n=246)\end{array}$ & $\begin{array}{l}60.13 \\
60.33\end{array}$ & $\begin{array}{l}23.69 \\
23.37\end{array}$ & 0.0906 & 0.928 \\
\hline Synthesis & $\begin{array}{l}\operatorname{Exp}(n=231) \\
\text { Control }(n=246)\end{array}$ & $\begin{array}{l}55.45 \\
63.41\end{array}$ & $\begin{array}{l}29.08 \\
28.69\end{array}$ & 3.023 & $<0.003$ \\
\hline Evaluation & $\begin{array}{l}\operatorname{Exp}(n=231) \\
\text { Control }(n=246)\end{array}$ & $\begin{array}{l}27.06 \\
20.16\end{array}$ & $\begin{array}{l}28.42 \\
21.40\end{array}$ & 3.004 & $<0.003$ \\
\hline
\end{tabular}

\section{Preferred Instructional Methods for Ecology}

Teachers were asked to indicate the instructional methods they preferred. Responses from the twelve teachers who participated in the study are presented in Table 3. From the data served, nine $(75 \%)$ of the twelve teachers were reported prefer to use the instructional method which involves three components i.e. lecture, students' individual activities, and few practical lessons in the same time. The teachers cited the following three reasons for always choosing the method. One, the method is effective for clear and coherent presentation of ecology concepts and terminologies which are abstract. Two, the method is effective in saving time thus allowing for early syllabus coverage resulting into ample time available for students to carry out revision activities. Three, as their schools are lack of adequate apparatus and equipment for practical lessons, but the method could still allow them to conduct demonstrations. These results might imply that biology classrooms are dominated by direct methods of instruction where teachers have custody of knowledge to be learnt and transmit it to learners who are mostly passive recipients.

Moreover, two (16.67\%) of the teachers who participated in this study indicated that they commonly use the methods which accommodates lecture, group activities, classroom discussion, and presentation. There were two undergirding reasons supported the teachers' choice. First, working in groups enables the students to share their learning experiences. As the students' attention and interest are improved, the strong engagement of students' activities will be enacted. They learn what they face during they are immersed in the social area (Hakkarainen et al., 2015). As the consequences, the effective learning is well conducted. Second, group discussion and presentation activities are the two proper ways in improving students' understanding and memories about the materials learned.

Only one $(8.71 \%)$ of the twelve teachers who implemented the teaching method which involved lecture, note elaborations, and tests. The teacher reasoned that his/her students were slow learners and that there were few biology textbooks in the school. Note elaboration was done during learning process by considering the lack of biology textbooks in the school. Meanwhile, the tests given were utilized as the instruments in drilling the students exercise in solving various questions related to the concepts learned.

Table 3. Preferred instructional methods for ecology

\begin{tabular}{llcc}
\hline & & Response & Percentage (\%) \\
\hline I & Lecture, elaborate notes and class tests & 1 & 8.71 \\
II & Lecture, Individual activities and few practical lessons & 9 & 75.00 \\
III & Lecture, group activities, class discussion and presentations & 2 & 16.67 \\
\hline
\end{tabular}




\section{Learners' attitude toward constructivism}

In order to ascertain the overall attitude of students towards the constructivist instructional approach, the responses from all students who were involved in this study, either as participant in experimental group or the control one as well as they who gave their responses in the attitude questionnaire, were analyzed. The analysis results are served in Table 4. As served in the table, it can be seen that there was a significant difference of female students' response $(M=58.30, S D=9.15, N=150)$ over male students $(M=53.14, S D=8.24, N=146)$, $t(294)=5.18, p<0.001$.

In addition, this finding leads to the conclusion that learners have positive attitude towards constructivist instructional approach. Generally, secondary school students gave more positive responses towards the use of constructivist instructional approach compared to the conventional one. This can be proven by the data which show that the mean of attitude score (measured with attitude questionnaire), the both boys and girls, were more than $50 \%$. This implies that the both female and male students liked to learn in the environment where they get the opportunities to actively participate in constructing their knowledge.

Table 4. Students' attitude towards the constructivist instructional methods

\begin{tabular}{rcccc}
\hline Gender & Mean & Std. Dev. & t-value & p-value \\
\hline Girls $(\mathrm{N}=150)$ & 58.3 & 9.15 & \multirow{2}{*}{5.18} & $<0.001$ \\
Boys $(\mathrm{N}=146)$ & 53.14 & 8.24 & & \\
\hline
\end{tabular}

\section{Teacher's attitude towards the application of constructivism}

Teachers who participated in the study were asked to respond to a set of questions which assessed their attitude towards an application of constructivism in teaching and learning biology. The results are presented in Table 5.

Table 5. Teachers' attitude towards application of constructivism

\begin{tabular}{|c|c|c|c|c|c|}
\hline Teacher's Attitude & SD (\%) & $\mathrm{D}(\%)$ & $\mathbf{N}(\%)$ & $\mathbf{A}(\%)$ & SA (\%) \\
\hline Constructivist approach leads to higher learner achievement & 28.4 & 19.6 & 2 & 12.3 & 37.7 \\
\hline Constructivist methodologies can be applied easily in a classroom setting & 48.4 & 17.3 & 5.9 & 17.5 & 10.9 \\
\hline $\begin{array}{l}\text { My school support constructivism as a pedagogical approach with enhanced } \\
\text { learning }\end{array}$ & 38.6 & 29.4 & 1 & 8.9 & 22.1 \\
\hline My students enjoy constructivist learning approaches & 29.6 & 13.5 & 32.3 & 10.2 & 14.4 \\
\hline I enjoy applying constructivism in my classes & 46.6 & 18.8 & 12.6 & 13.2 & 8.8 \\
\hline
\end{tabular}

The findings, as served in Table 5, show that teachers were less optimistic toward application of constructivist instructional approach in classroom. Approximately $48.4 \%$ of the teachers showed strong disagreement with the statement that 'Constructivist methodologies could be applied easily in a classroom setting'. As to whether students enjoyed constructivist learning environments, $32.3 \%$ were neutral. However, most of the teachers (37.7\%), in contrast, indicated strong agreement with the statement that "Constructivist approach leads to higher learner achievement".

Furthermore, $38.6 \%$ of the teachers indicated strong disagreement toward the implementation constructivist instructional approach by their respective schools. These finding leads to an understanding that as the teachers were aware about the pedagogical values of constructivism, they rarely applied it in classroom due to inadequacy support as considerable as incompatibility of classroom environments to this approach.

\section{The availability of facilities for teaching and learning ecology}

Ecology learning requires practical investigations of the environment to know where exactly the different organisms live. To conduct the effective ecology learning, schools should provide adequate facilities which enable students to carry out the investigations. The facilities considered in this study are basic requirements which mostly needed by students to conduct investigations in school environment (served in Table 6).

The data in Table 6 indicate that schools which participated in the study did not provide the all facilities and equipment needed in ecology learning. The most expensive facility cited in the study was open field ground and apparently all the schools which participated in the study have it. The remaining facilities were of lesser value but were not uniformly possessed by the schools. 


\section{Sweep nets and quadrats}

Sweep nets and quadrats are key facilities used in carrying out ecological field. It was, therefore, necessary for the study to survey the presence of these two items in the participant schools. Table 7 presents a summary of the number of sweep nets and quadrats in the participant schools.

Data in Table 6 shows that out of the 12 schools which took part in the study, only five (41.67\%) were having quadrats, and out of the five schools, three of them had ten quadrats while the other two schools had only two quadrats each. The seven remaining schools $(58.3 \%)$ did not have even a single quadrat. The data in the table also indicate that eight $(66.67 \%)$ of the 12 schools had sweep nets and the four (33.3\%) remaining schools did not have it.

Table 6. Facilities and Equipment's for teaching and learning ecology

\begin{tabular}{llcccc}
\hline & \multicolumn{1}{c}{ Facilities and Equipment } & \multicolumn{2}{c}{ Schools Having } & \multicolumn{2}{c}{ Schools Not Having } \\
\cline { 3 - 5 } & & No & $\%$ & No & $\%$ \\
\hline 1. & Quadrats & 5 & 41.67 & 7 & 58.3 \\
2. & Sweep Nets & 8 & 66.7 & 4 & 33.3 \\
3. & Open Field & 12 & 100 & 0 & 0 \\
4. & Manila or Sisal rope & 9 & 75 & 3 & 25 \\
5. & Flip charts or Manila papers & 10 & 83.3 & 2 & 16.7 \\
6. & Indelible Ink & 8 & 58.3 & 4 & 44.7 \\
7. & Variety of Biology T/books & 11 & 91.7 & 1 & 8.3 \\
8. & Panga/Jembe/Shovel & 10 & 83.3 & 2 & 16.7 \\
9. & Specimen bottles/Polythene bags & 10 & 83.3 & 4 & 16.7 \\
10. & Tape measure/metre rule & 12 & 100 & 0 & 0 \\
11. & Cobalt chloride paper & 9 & 75 & 3 & 25 \\
\hline
\end{tabular}

Table 7. Sweep nets and quadrats

\begin{tabular}{cccc}
\hline Number of Quadrats in School & Number of Schools & Number of Sweep Nets in School & Number of Schools \\
\hline 0 & 7 & 0 & 4 \\
1 & 0 & 1 & 2 \\
2 & 2 & 2 & 2 \\
3 & 0 & 3 & 2 \\
4 & 0 & 4 & 0 \\
5 & 0 & 5 & 0 \\
6 & 0 & 6 & 1 \\
7 & 0 & 7 & 0 \\
8 & 0 & 8 & 0 \\
9 & 0 & 9 & 0 \\
10 & 3 & 10 & 1 \\
More than 10 & 0 & More than 10 & 0 \\
\hline
\end{tabular}

Quadrats and sweep nets are basic facilities used in practical activities to estimate population of organisms. Since these facilities were lacking in many schools or were in scarce quantities in the schools, the implication is that biology teachers are not able to organize for practical lessons or conduct effective demonstration. These findings are supported by KNEC report of year 2007 on KCSE examination.

\section{Challenges encountered during teaching ecology}

The challenges discussed here are factors cited by biology teachers who participated in the study (Chin \& Osborne, 2008; Feyzioğlu, 2012; Pillay, 2016; Wang, 2014). The factors are considered hindrances to constructivist approach in teaching and learning ecology (Dennick, 2016; Hedden, Worthy, Akins, SlingerFriedman, \& Paul, 2017; Valderrama-Hernández, Alcántara, \& Limón, 2017). The all challenges mentioned by the teachers have been summarized into seven points i.e. 1) ecology topic is broad and stressful to teach and cover effectively within the limited time provided by school syllabus coverage deadlines; 2) although ecological field trips are essential in teaching and learning ecology, most of the teachers felt that it is difficult (Allybokus, 2015; Jepketer, 2017; Jidamva, 2012) and expensive to organize; 3) the double lessons allocated for practical activities in the biology time table do not provide adequate time to conduct ecology practical activities (Gideon M. Mwanda et al., 2016; Mukhwana, 2016; Ngesu et al., 2014; Nyongesa, 2015; Ouko et al., 2017; Vidija, 2015); 4) resource materials including variety of biology reference books are either not available in schools or if available, are in inadequate quantities compared to the number of students; 5) frequent interruption of classes or school programs due to fee collection procedures and other school activities resulting in increasing student 
absenteeism from classes; 6 ) terminologies in the ecology topic are difficult so the learners require more time to learn the terms; 7) the time for teaching ecology topic is normally during a dry season when there is inadequate fauna and flora.

This study considered the challenges cited by the biology teachers as novice ideas that do not reflect strong conceptions of the nature of biology and instructional practices involved in teaching and learning biology. National Research Council (2000) stated that for teachers with less years of teaching experience, their epistemological believes about science and ways of learning science are not stable and are easily buckled by students' demand for less class work. Thus, it is crucial to improve their self-regulated thinking (Boruchovitch \& Ganda, 2013). Contextual learning such as environmental conditions around and the school itself affect their instructional methods. Some of the facilities needed for ecology lessons like sweep nets and quadrats are simple and can be innovatively prepared by the teachers and the students. School authorities should improve communication patterns with parents to make organization of field trips easy and to reduce time wastage in fee collection. Biology teachers can use strategies that ease learning of terminologies.

\section{CONCLUSION}

The findings of this study revealed that constructivist instructional approach pay positive influence on learners' achievement in biology. In the same vein, there was a significant gender difference between male and female students' achievement in biology when constructivist instruction is used. Furthermore, students in single sex girls schools achieved the highest gain in mean, followed by students in the category of mixed boys and girls with the least gain registered by the students in single sex boys schools and thus indicating that constructivist instructional methods leads to higher achievement in single sex girls schools. On the other hand, the findings of this study revealed that students had positive attitude towards the constructivist instructional methods and that girls were more positive towards the constructivist instructional method as compared to the boys. This study therefore concludes that the constructivist instructional method is effective in improving learner achievements in biology and should therefore be adopted in secondary schools in teaching biology.

Based on these findings, biology teachers should be encouraged to use constructivist method of instruction, since the method is more effective in learning biology compared to conventional. Since learner attitude is important and has implications on performance, biology teachers should be able to adopt the constructivist instructional approach of instruction as it eliminates some of the classroom practices that do not encourage students to develop positive attitude towards biology. Finally, school administrators should be encouraged to improve on management of academic programs by providing necessary facilities required for instructional purposes specifically variety of textbooks, apparatus and equipment for practical lessons to promote constructivist approach of learning.

\section{REFERENCES}

Adams, P. (2006). Exploring social constructivism: Theories and practicalities. International Journal of Primary, Elementary and Early Years Education, 34(3), 243-257. doi: http://doi.org/https://doi.org/10. 1080/03004270600898893

Allybokus, B. S. (2015). The implementation of learner-centred teaching in Mauritian state secondary schools : examining teachers 'beliefs and classroom practice. Institute of Education University College London. Retrieved from http://discovery.ucl.ac.uk/10021912/1/27 4 15- EdD Theisis FINAL .pdf

Andersen, I. G., \& Andersen, S. C. (2017). Student-centered instruction and academic achievement: Linking mechanisms of educational inequality to schools' instructional strategy. British Journal of Sociology of Education. doi: http://doi.org/10.1080/01425692.2015.1093409

Bloom, L. (2000). Pushing the limits on theories of word learning. Monographs of the Society for Research in Child Development, 65, 124-135. doi: http://doi.org/10.1111/1540-5834.00100

Boruchovitch, E., \& Ganda, D. R. (2013). Fostering self-regulated skills in an educational psychology course for Brazilian preservice teachers. Special Issue on Fostering Self-Regulated Learning in Intervention and Regular Teaching. Retrieved from https://www.frontiersin.org/articles/10.3389/feduc.2018.00005/full

Chin, C., \& Osborne, J. (2008). Studies in science education students ' questions: A potential resource for teaching and learning science. Studies in Science Education, 44(1), 1-39. doi: https://doi.org/10.1080/ 03057260701828101

Connell, G. L., Donovan, D. A., \& Chambers, T. G. (2016). Increasing the use of student-centered pedagogies from moderate to high improves student learning and attitudes about biology. CBE Life Sciences 
Education, 15(1), 1-15. doi: http://doi.org/10.1187/cbe.15-03-0062

Dennick, R. (2016). Constructivism: Reflections on twenty five years teaching the constructivist approach in medical education. International Journal of Medical Education, 7, 200-205. doi: https://doi.org/10.5116 lijme.5763.de11

Eilam, E., \& Trop, T. (2012). Environmental attitudes and environmental behavior-which is the horse and which is the cart? Sustainability, 4(9), 2210-2246. doi: http://doi.org/10.3390/su4092210

Feyzioğlu, E. Y. (2012). Science teachers' beliefs as barriers to implementation of constructivist-based education reform. Journal of Baltic Science Education, 11(4), 302-317. Retrieved from http://www. scientiasocialis.|t/jbse/files/pdf/vol11/302-317.Feyzioglu_Vol.11_4.pdf

Gideon M. Mwanda, Paul Odundo, Ronnie Midigo, \& Owino S. Mwanda. (2016). Adoption of the constructivist learning approach in secondary schools in Kenya: Focus on learner achievement in biology by class category. US-China Education Review A, 6(1), 31-44. doi: http://doi.org/10.17265/2161-623x/2016.01.0 03

Hakkarainen, K., Paavola, S., Kangas, K., \& Seitamaa-Hakkarainen, P. (2015). Sociocultural perspectives on collaborative learning. The International Handbook of Collaborative Learning. London: Routledge. doi: http://doi.org/10.4324/9780203837290.ch3

Hedden, M. K., Worthy, R., Akins, E., Slinger-Friedman, V., \& Paul, R. C. (2017). Teaching sustainability using an active learning constructivist approach: Discipline-specific case studies in higher education. Sustainability (Switzerland), 9(8), 1-18. doi: https://doi.org/10.3390/su9081320

Hsu, H. C. K., Wang, C. V., \& Levesque-Bristol, C. (2019). Reexamining the impact of self-determination theory on learning outcomes in the online learning environment. Education and Information Technologies, 1-16. doi: http://doi.org/10.1007/s10639-019-09863-w

Izzo, M. V. (2012). Universal design for learning: Enhancing achievement of students with disabilities. In Procedia Computer Science (Vol. 14, pp. 343-350). doi: http://doi.org/10.1016/j.procs.2012.10.039

Jafari Amineh, R., \& Davatgari Asl, H. (2015). Review of constructivism and social constructivism. Journal of Social Sciences, Literature and Languages, 1(1), 9-16. Retrieved from https://pdfs.semanticscholar.org/ 3890/3f4a7255496f75124d639e14e9b810c17370.pdf

Jang, H., Kim, E. J., \& Reeve, J. (2016). Why students become more engaged or more disengaged during the semester: A self-determination theory dual-process model. Learning and Instruction, 43, 27-38. doi: http://doi.org/10.1016/j.learninstruc.2016.01.002

Jepketer, A. (2017). Influence of teaching strategies on students' performance in academic achievement and co-curricular activities in public secondary schools in Nandi county, Kenya. School of Education, Kenyatta University. Retrieved from https://ir-library.ku.ac.ke/handle/123456789/18368

Jidamva, G. B. (2012). Understanding and improving quality of secondary school, conceptions among teachers in Tanzania (1st ed.). Åbo, Finland: Ảbo Akademi University Press. Retrieved from https://www.academia.edu/28202912/Understanding_and_Improving_Quality_of_Secondary_School_E ducation_Conceptions_among_Teachers_in_Tanzania_Understanding_and_Improving_Quality_of_Sec ondary_School_Education_Conceptions_among_Teachers_in_Tanzania

Kharb, P., Samanta, P. P., Jindal, M., \& Singh, V. (2013). The learning styles and the preferred teachingLearning strategies of first year medical students. Journal of Clinical and Diagnostic Research, 7(8), 1089-1092. doi: http://doi.org/10.7860/JCDR/2013/5809.3090

Kimmerle, J., Moskaliuk, J., Oeberst, A., \& Cress, U. (2015). Learning and Collective Knowledge construction with social media: A process-oriented perspective. Educational Psychologist, 50(2), 120-137. doi: http://doi.org/10.1080/00461520.2015.1036273

Laal, M., Naseri, A. S., Laal, M., \& Khattami-Kermanshahi, Z. (2013). What do we achieve from learning in collaboration? In Procedia - Social and Behavioral Sciences (Vol. 93, pp. 1427-1432). doi: http://doi.org/10.1016/j.sbspro.2013.10.057

Lai, E. R. (2011). Collaboration: A literature review. Pearson's Research Reports. Retrieved from https:// images.pearsonassessments.com/images/tmrs/Collaboration-Review.pdf

Lord, T. R. (1999). A comparison between traditional and constructivist teaching in environmental science. Journal of Environmental Education. doi: http://doi.org/10.1080/00958969909601874

McKnight, K., O'Malley, K., Ruzic, R., Horsley, M. K., Franey, J. J., \& Bassett, K. (2016). Teaching in a digital age: How educators use technology to improve student learning. Journal of Research on Technology in Education, 48(3), 194-211. doi: http://doi.org/10.1080/15391523.2016.1175856

Mensah, E. (2015). Exploring constructivist perspectives in the college classroom. SAGE Open, 5(3), 1-14. 
doi: http://doi.org/10.1177/2158244015596208

Montrieux, H., Vanderlinde, R., Schellens, T., \& De Marez, L. (2015). Teaching and learning with mobile technology: A qualitative explorative study about the introduction of tablet devices in secondary education. PLOS ONE, 10(12), 1-17. doi: http://doi.org/10.1371/journal.pone.0144008

Mukhwana, W. J. (2016). How can institutional capacity be improved to bolster performance in biology in secondary schools ?: A focus on Eldoret Municipality, Kenya. International Journal of Humanities and Social Science, 6(11), 211-221. Retrieved from https://www.ijhssnet.com/journals/Vol_6_No_11_ November_2016/24.pdf

National Research Council. (2000). How people learn brain, mind, experience, and school - Early childhood development and Learning (Expanded E). Washington, DC: The National Academies Press. doi: http://doi.org/10.17226/9853

Ngesu, L. M., Gunga, S., Wachira, L., \& Kaluku, E. N. (2014). Some determinants of students performance in biology in KCSE : A case of Central Division of Machakos District. International Journal of Innovative Research \& Studies, 3(1), 174-186. Retrieved from http://erepository.uonbi.ac.ke/handle/11295/71719

Nyongesa, K. W. (2015). A teachers perspective on the challenges in the delivery of content and performance in biology: A case of Bungoma District, Kenya. Kabarak Journal of Research \& Innovation, 3(2), 23-42. Retrieved from http://eserver.kabarak.ac.ke:8082/ojs/index.php/journal1/article/view/86

Öhrstedt, M., \& Lindfors, P. (2018). First-semester students' capacity to predict academic achievement as related to approaches to learning. Journal of Further and Higher Education. doi: http://doi.org/10.1080/0309877X.2018.1490950

Ouko, F. O., Anditi, Z. O., \& Githua, B. N. (2017). Teachers' perceptions on effectiveness of the KCSE biology practical assessment approach in testing experimenting skills in secondary schools in Siaya County, Kenya. International Journal of Sciences: Basic and Applied Research (IJSBAR), 34(2), 120-136. Retrieved from http://gssrr.org/index.php?journal=JournalOfBasicAndApplied\&page=article\&op=view\& path $\% 5 B \% 5 D=7503 \&$ path $\% 5 B \% 5 D=3540$

Piaget, J., \& Inhelder, B. (1964). The child's conception of space. 55 Fifth Avenue, New York: W. W. Norton \& Company, Inc. Retrieved from https://www.scribd.com/document/324620370/Jean-Piaget-The-Child-sConception-of-Space-pdf

Pillay, J. (2016). Keystone Life Orientation (LO) teachers: Implications for educational, social, and cultural contexts. South African Journal of Education, 32(2), 167-177. doi: https://doi.org/10.15700/saje.v32n2 a497

Powell, K. C., \& Kalina, C. J. (2009). Cognitive and social constructivism: Developing tools for an effective classroom. Education, 130(2), 241. doi: http://doi.org/10.1037/0022-0663.93.3.571

Shabani, K. (2016). Applications of Vygotsky's sociocultural approach for teachers' professional development. Cogent Education, 3(1), 1-10. doi: http://doi.org/10.1080/2331186X.2016.1252177

Shabani, K., Khatib, M., \& Ebadi, S. (2010). Vygotsky's zone of proximal development: Instructional implications and teachers' professional development. English Language Teaching, 3(4), 237-248. doi: http://doi.org/10.5539/elt.v3n4p237

Thomas, A., Menon, A., Boruff, J., Rodriguez, A. M., \& Ahmed, S. (2014). Applications of social constructivist learning theories in knowledge translation for healthcare professionals: A scoping review. Implementation Science, 9(1), 1-20. doi: http://doi.org/10.1186/1748-5908-9-54

Thorndike, R. M., \& Thorndike-Christ, T. M. (2010). Measurement and evaluation in psychology and education (8th Ed.). New York, US: Pearson. Retrieved from https://openlibrary.org/books/OL10085424M/Mea surement_and_Evaluation_in_Psychology_and_Education_(8th_Edition)

Valderrama-Hernández, R., Alcántara, L., \& Limón, D. (2017). The complexity of environmental education: Teaching ideas and strategies from teachers. In Procedia - Social and Behavioral Sciences (Vol. 237, pp. 968-974). doi: https://doi.org/10.1016/j.sbspro.2017.02.137

van Riesen, S. A. N., Gijlers, H., Anjewierden, A., \& de Jong, T. (2018). The influence of prior knowledge on experiment design guidance in a science inquiry context. International Journal of Science Education, 40(11), 1327-1344. doi: http://doi.org/10.1080/09500693.2018.1477263

Verenikina, I. M. (2010). Vygotsky in Twenty-First-Century research. In J. Herrington \& B. Hunter (Eds.), World Conference on Educational Multimedia, Hypermedia and Telecommunications (pp. 16-25). Chesapeake, VA.: AACE. Retrieved from https://ro.uow.edu.au/cgi/viewcontent.cgi?referer=https://www. google.com/\&httpsredir=1\&article=2337\&context=edupapers

Vidija, M. D. (2015). Impact of school based practical assessment on learner achievement in biology in 
secondary schools in Kakamega County, Kenya. Master of Education, University of Nairobi. Retrieved from https://pdfs.semanticscholar.org/8c4a/5c89cc81733c4540d03e6d122c0b1f9b4f29.pdf

Vygotsky, L. S. (1978). Mind in society: The development of higher psychological processes. Cambridge, Mass.: Harvard University Press. Retrieved from http://ouleft.org/wp-content/uploads/Vygotsky-Mind-inSociety.pdf

Wang, P. (2014). Teachers' implementation of constructivist teaching: Does career motivation make a difference? ProQuest Dissertations and Theses. Indiana University of Pennsylvania. Retrieved from https://knowledge.library. iup.edu/cgi/viewcontent.cgi?article=2294\&context=etd

Wang, L., Bruce, C., \& Hughes, H. (2011). Sociocultural theories and their application in information literacy research and education. Australian Academic and Research Libraries, 42(4), 296-308. doi: http://doi. org/10.1080/00048623.2011.10722242

Zenda, R. (2017). Essential teaching methods to enhance learner academic achievement in physical sciences in rural secondary schools: A South African case study. Information and Learning Science, 118(3-4), 128. doi: http://doi.org/10.1108/LS-03-2017-0014 